\title{
Silicon bioavailability in exocarp of Cucumis sativus Linn.
}

\author{
Deepika Tripathi $^{1} \cdot$ Mrigank Mauli Dwivedi $^{2} \cdot$ Durgesh Kumar Tripathi $^{3}$. \\ Devendra Kumar Chauhan ${ }^{1}$
}

Received: 6 December 2016/Accepted: 7 September 2017/Published online: 8 November 2017

(C) Springer-Verlag GmbH Germany 2017

\begin{abstract}
Scanning electron microscopy (SEM) and electron probe micro-analyzer (EPMA) techniques have been used to detect the silicon bioavailability in the exocarp of warty cucumber surface. Warts appear at the time of anthesis and are remnant part of spines/trichomes which on further fruit maturation abscised from the exocarp. Results of EPMA and phytolith analysis clearly revealed that the surface of exocarp (fruit) of Cucumis sativus Linn. containing warts has greater quantity of silicon as compared to the other part of the fruit. Besides silicon, some other elements were also found, on the fruit exocarp and its surrounding area. The other elements are magnesium $(\mathrm{Mg})$, aluminum (Al), phosphorus $(\mathrm{P})$, sulfur $(\mathrm{S})$, potassium $(\mathrm{K})$, calcium $(\mathrm{Ca})$, iron $(\mathrm{Fe})$, nickel $(\mathrm{Ni})$, copper $(\mathrm{Cu})$, and sodium. The percentage of silica is highest followed by $\mathrm{Ni}$, $\mathrm{Ca}, \mathrm{Al}, \mathrm{P}, \mathrm{Mg}, \mathrm{Fe}, \mathrm{S}, \mathrm{Cu}, \mathrm{K}$, and $\mathrm{Cl}$. Thus, this study clearly demonstrates that Cucumis sativus Linn. fruits which are used as salads and appetizers on daily basis are loaded with
\end{abstract}

Durgesh Kumar Tripathi

dktripathiau@gmail.com

$\triangle$ Devendra Kumar Chauhan

dkkchauhanau@yahoo.com

Deepika Tripathi

deepika.env@gmail.com

Mrigank Mauli Dwivedi

mmdwivedi@gmail.com

1 D. D. Pant Interdisciplinary Research Laboratory, Department of Botany, University of Allahabad, Allahabad 211002, India

2 National Centre of Experimental Mineralogy and Petrology, University of Allahabad, Allahabad, India

3 Centre of Advanced Study in Botany, Banaras Hindu University, Varanasi 221005, India silicon and other useful elements and possess numerous health benefits.

Keywords Cucumber - Electron probe micro-analyzer . Exocarp $\cdot$ Silicon $\cdot$ Warts

\section{Introduction}

Terrestrial vegetation is a vast sink for biogenic silica which is widely present in the soil and absorbed by plant in the form of silicic acid (Epstein 1999). More and more evidences indicated strong control of silica biogeochemistry by plant communities particularly by members of Poaceae (Kaufman et al. 1999; Derry et al. 2005). Silica is usually found in the plant bodies named as phytoliths or opal phytolith in which hydrogen get bonded with cellulose molecules in the cell walls as silicon dioxide, i.e., $\mathrm{SiO}_{2 \text {-- }}$ $\mathrm{nH}_{2} \mathrm{O}$ (Kaufman et al. 1999; Tripathi et al. 2012a, b). Although silica is not considered as an essential element for the plants in the classical sense, however, many studies demonstrated that silica is an important constituent of plant cell wall which provides rigidity to monocot leaves and it takes part in many physiological processes which increases plants resistance to abiotic and biotic stresses (Epstein 1999; Tripathi et al. 2014, 2016, 2017). Uptake of silicon has been shown to increase the rigidity of leaves and the several other benefits to plants in dynamic environments. Silicon deposition is not limited to occur only in cell wall and intercellular spaces, but it is also deposited in cytoplasm and vacuoles, which are closely connected to the cell wall proteins and bio-molecules involved in its formation (Harrison 1996; Schoelynck et al. 2010). Silicon is not only a structural constituent of plants but also it takes part in many physiological processes and provides protection from 
external stimulations (Sangster et al. 2001; Tripathi et al. 2012a, b). Therefore, silicon is an important component for plant growth and development under various stresses (Epstein 1999; Tripathi et al. 2014, 2016, 2017). It has been suggested that silicon is mainly present in the form of aluminosilicates and polymeric silica, which is not readily available to the biological system (Kayongo-Male and Jia 1999). Various studies on the solubility of silicon in the gastrointestinal tract of animals show that very few amount of dietary silicon is responsible for the rate of production of absorbed silicon; for example, silicon in food and beverages easily get absorbed (Carlisle 1986; Kayongo-Male and Jia 1999). Silica in its inorganic form $\mathrm{SiO}_{2}$ is not so useful for humans, and thus, plants change inorganic form of silica into its organic form, which is orthosilicic or monosilicic acid $\mathrm{Si}(\mathrm{OH})_{4}$. This form of silica is bioavailable for human consumption as it is easily absorbed form of Si in men (Jugdaohsingh et al. 2002). It has also noticed that plant-based products provide more silicon than animalbased products as they contain very little amount of silicon (Pennington 1991).

Cucumis sativus Linn. is one of the widely cultivated plants of family Cucurbitaceae, it is an essential companion of salads which creates flavor in foods. It is the fourth most cultivated plant in the world and the Cucumis sativus var. hardwiki is widely cultivated in Indo-Gangetic plains (Fuller 2006, Sebastian et al. 2010). It is believed that Cucumis sativus Linn. was originated and domesticated in the Indian subcontinent further around 2000 years ago it spread to China (Paris et al. 2011). It is an annual creeping plant, which grows in temperate and tropical climate. The plants are mostly grown in warm season, as they are frost sensitive (Welbaum 2014). The fruits of Cucumber are botanically classified as pepo, which are of many different sizes, shapes, and colors; they vary in their texture of fruit cover.

Cucumbers are composed of nearly $90 \%$ water and valued for providing a variety of phytonutrients, including vitamins and minerals (website whfoods.com). It has been well documented that every plant family did not accumulate silica, but those families which accumulate silica in their tissues accumulate it in different amount (Epstein 1999). Family Cucurbitaceae is among those important families which accumulate silicon in sufficient amount (Bozarth 1987). Silicon which has not yet received much importance regarding health is now recognized as a vital mineral for human health and it is equally beneficial for plant growth and development.

It is well known that Cucurbits are noticeably good silica accumulators, but how much silica is found in its fruits is not very well known. Therefore, the main objective of this work is to study the $\mathrm{Si}$ content of cucumber fruit exocarp, both inside and outside the wart. The cucumber selected for study showed numerous warts on its surface which is also known as warty cucumbers and pickling cucumber. The fruit surface may have variations in the type and number of warts, which generally appears in young fruit.

\section{Materials and methods}

\section{Sample collection and phytolith analysis}

Young Cucumis sativus Linn. fruits containing numerous warts over fruit surface were taken for experiment. A thin section from the exocarp of fruit was cut including wart. For preliminary analysis, the cross section of fruit surface was cut and was seen under light microscope (Olympus $\mathrm{CH} 2 \mathrm{Oi}$ ). For the phytolith analysis of exocarp of fruit surface, dry ashing technique proposed by Piperno's (2006) has been applied. For this, a piece of peeled exocarp of cucumber was used, after washing and drying overnight in oven at $60{ }^{\circ} \mathrm{C}$. The dried exocarps were taken into the crucible and then placed in muffle furnace at $500-600{ }^{\circ} \mathrm{C}$ temperature. After $8 \mathrm{~h}$, the ash is treated with nitric acid to dissolve the organic content. The residue was rinsed many times; finally, a little amount of ash was taken to prepare the slides by mounting it in Canada balsam. The slides were observed under light microscope (Olympus CH2Oi).

\section{Section cutting and staining with methyl red}

Hand sections of warts over fruit surface of cucumber were made and stained with Methyl Red and then mounted in glycerin according to the method of Dayanandan et al. (2005). Images were taken by a digital camera linked to an optical microscope using the software image tool.

\section{Scanning electron microscopic (SEM) analysis}

The SEM photography was performed at BSIP (Birbal Sahni Institute for Paleobotany, Lucknow). The dehydrated thin sections of cucumber were cut, critical point dried, mounted on stub, and then coated with gold palladium alloy using POLARON sputter coater. The Scanning Electron Microscopy was done using LEO 430 model.

\section{Electron probe micro-analyzer (EPMA) analysis}

Before analysis, the warts over fruit surface of cucumber were dehydrated through the standard dehydration process using alcohol series. Then, the sample was dried using vacuum evaporator. After that, the sample was coated with $30 \mathrm{~nm}$ layer of carbon under vacuum using Vacuum Evaporator (Jeol JEE-420). Then, WDX (wavelength 
dispersive X-ray spectroscopy and BEI (backscattered electron imaging) were performed using electron probe micro-analyzer model (Jeol JXA8100, Japan) at National Centre of Experimental Mineralogy and Petrology, University of Allahabad. The electron beam of $15 \mathrm{keV}$ was used in this analysis. The beam current of $1 \times 10^{-7}$ and $2 \times 10^{-7}$ Amp was used for BEI and WDX analysis, respectively. Probe diameter of $20 \mu \mathrm{m}$ was used for WDX analysis. Five points were taken from wart and non-wart areas to analyze the silica percentage located both inside and the surrounding area outside wart. In this analysis, the presence of elements lighter than carbon has been omitted.

\section{Results and discussion}

Silicon is recognized as one of the most beneficial element in plants, animals, and human beings, so its multifarious role should be well known. However, information related with the Si content of fruits, vegetables, and food materials is still less known (van Dyck et al. 2000). Powell et al. (2005) provide compositional data of $\mathrm{Si}$ component in various food products including Cucumis sativus Linn. In the present study, bio-silica availability in warts of the Cucumis sativus Linn. fruit containing more warts on its surface was selected for the study (Fig. 1a). Warts appear after anthesis and possess the same cell structure of the pericarp (Barber 1909). Each wart contains an emergence of thickened pitted walls (Barber 1909). At apex, the warts contain jointed conical hair with thickened walls (Barber 1909). The inner sunken foot and cross walls are pitted and thickened. In the further developmental stage, the trichomes disappear. Besides warts, the immature fruit also contains small capitate hairs over the surface of immature fruit but disappear early, without leaving a scar. Figure 1a shows a fruit of cucumber having numerous warts which are scattered here and there on the fruit surface; however, Fig. 1b shows the surface view of which polygonal and hexagonal cells without intercellular spaces. Furthermore, Fig. 1c depicts the arrangement of silicified cells which is generally called as phytoliths; these cells are systematically arranged and conjoined with each other. The diagrammatic representation of the cells present inside the wart area is mostly silicified cell walls (Fig. 1d). It has been reported that Methyl Red successfully stained the phytoliths or silicified cells of the plants (Dayanandan et al. 2005), so for more better view of silica/phytoliths, the warty part of the cucumber has been stained with Methyl Red (Fig. 1e) which shows some colored area that confirmed the deposition of silica on warty part. Moreover, scanning electron microscopy (SEM) has also been used to observe the morphology of silicified cells of the warty part of cucumber which shows that cells are compactly arranged with silicified transverse wall and thickenings which are present on the inner tangential and radial walls of the cells (Fig. 1f) and transverse section showing inner structure of the wart (Fig. 2a-c).

Figure 2a clearly shows detailed internal structure of wart, showing rounded hypodermal cells inside and outside the wart. Figure $2 b$ shows transition zone or junction of outer and inner structures of the wart. From these results, it is evident that the cells present outside the wart become somewhat smaller than those present inside (Fig. 2a, b). Besides this, these cells appear rather compact, while Fig. $2 c$ is an enlarged view of the cells present inside the wart which are somewhat large and rounded. In addition, to aid justification of the presence, amount, and the pattern of silica deposition, an electron probe micro-analyzer analysis was also carried out on the air dried section of fruit surface or exocarp, containing warts (Figs. 3, 4, 5). To perform these analysis, five points were randomly selected to study the exact percentage of silica in warty cucumber which is shown as 1-5 numbers in Fig. 3a. Besides this, the separate spectra of EPMA analysis of selected point 1-5 are given in Figs. 3b-d, 4a-f, 5a-f) respectively. An EPMA spectrum shows the lower and higher peaks of silica according to its percentage availability on cucumber fruit. It is evident from the composition map for EPMA analysis (Figs. 3, 4, 5) that the Si content was much higher in the region containing wart which is around a maximum of $99 \%$, while the adjoining region surrounding wart has deposited less silica (Table 1). The percent wise mineral composition of five selected locations is given in Table 1 . Among five selected locations, the silica percentage is the highest in point 2 followed by points 3, 1, 4, and 5, respectively. The points located inside wart region show a higher percentage of silica and the points outside the wart area show lower percentage (Figs. 3, 4, 5). Furthermore, the outer most point 5 shows lowest deposition of silica. The EDX analysis also revealed the presence of some other elements in traces like $\mathrm{Mg}, \mathrm{Al}, \mathrm{P}, \mathrm{S}, \mathrm{Cl}, \mathrm{Ca}, \mathrm{K}, \mathrm{Fe}, \mathrm{Ni}, \mathrm{Cu}$, and $\mathrm{Na}$, etc. The results clearly suggest that over all percentage on the basis of average of each selected point, $\mathrm{SiO}_{2}$ is highly present followed by the $\mathrm{NiO}, \mathrm{CaO}, \mathrm{Al}_{2} \mathrm{O}_{3}, \mathrm{P}_{2} \mathrm{O}_{5}$, $\mathrm{MgO}, \mathrm{FeO}, \mathrm{SO}_{3}, \mathrm{Cu}, \mathrm{K}_{2} \mathrm{O}, \mathrm{Cl}$, and $\mathrm{Na}_{2} \mathrm{O}$, respectively. The availability of these elements may confirm the nutritional value and importance of cucumber fruit for the humans and animals. Moreover, these nutrient elements also have unique functions and their balanced availability is essential for the metabolic systems of all living organisms (Soetan et al. 2010; Tripathi et al. 2015a). Silicon provided tolerance, to plants form abiotic and biotic stresses, as it gives mechanical strength to plant tissues (Sangster et al. 2001; Tripathi et al. 2012a, b, 2014, 2015b). Rogalla and Römheld (2002) have also been found that silicon is more 
Fig. 1 Fruit of Cucumis sativus having numerous warts

(a) shows the surface view of selected warty part (b), the arrangement of silicified cells (c), diagrammatic representation of the cells present inside the wart area (d), stained silicified cells warty part of the cucumber by methyl red (e), and SEM surface view of the selected warty part of Cucumber (f)

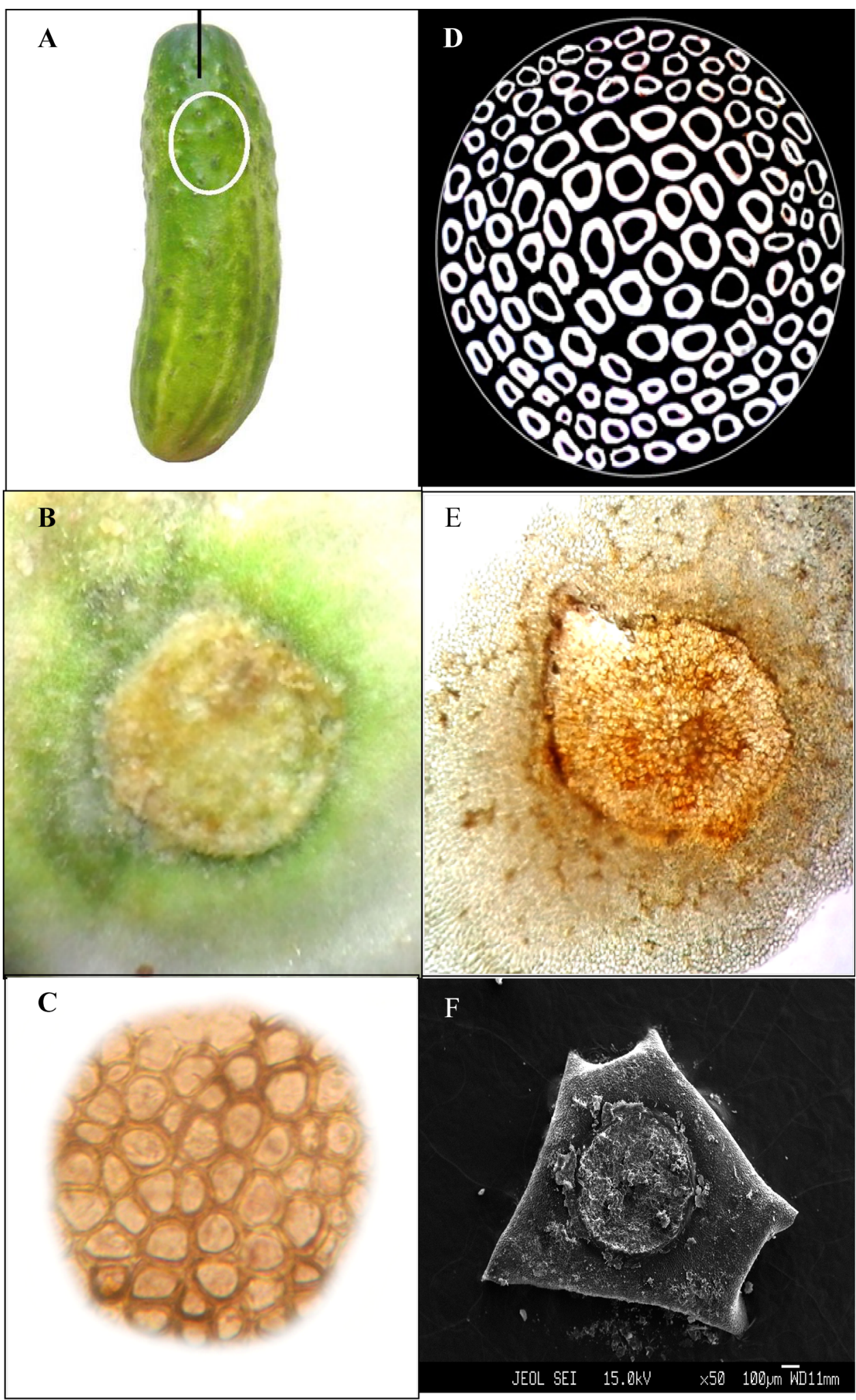

effective against Mn toxicity in Cucumis sativus Linn. plants.

Several studies show ample amount of evidences regarding accumulation, distribution, and deposition of silicon in plants, fruits, and vegetables, especially monocotyledons (Harrison 1996; Derry et al. 2005; Tripathi et al. 2012a, b; Vasanthi et al. 2012). In addition, silicon has also been reported to play a significant physical, biochemical, 

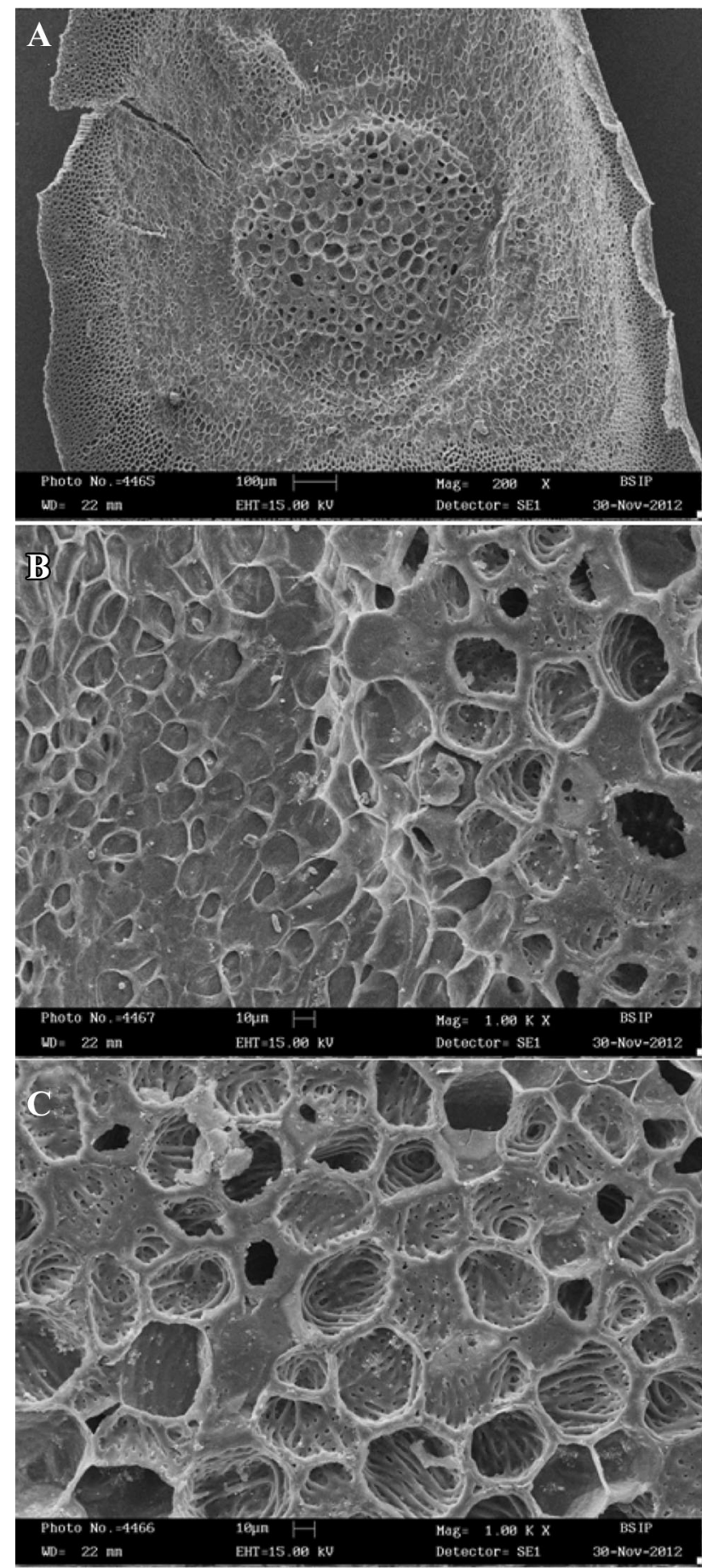

Fig. 2 Detailed internal structure of wart, showing rounded hypodermal cells inside and outside the wart, transition zone or junction of outer and inner structures, and enlarged view of the cells present inside the wart $(\mathbf{a}-\mathbf{c})$

and molecular role in plants, human, and animals, and considered as nutritionally important element (Epstein 1999; Tripathi et al. 2012a, b; Vasanthi et al. 2012; Seaborn and Nielsen 1993); whereas in humans, the role of silicon is more important as it is essential for maintaining skeletal health (Seaborn and Nielsen 1993). In general, animal and human beings ingest silicon through the food, vegetable, and feed materials and its most of the amount excreted by the faeces and urine, and thus, only a tiny amount is engrossed which plays a critical role in the body (Vasanthi et al. 2012).

To analyze the silicon content in cucumber fruits surface due to its wide consumption rate as a food material in human beings, a systematic attempt has been made in the present study. Various studies have revealed that cucumber accumulates silicon in various parts like fruits, trichomes, leaves, etc. (Bozarth 1987). For instance, Inamdar and Gangadhara (1975) reported glandular stalked trichomes which were observed occasionally on ovary of cucumber. Furthermore, Samuels et al. (1993) reported that in cucumber fruits, silicon is highly deposited in fruit rind and then flesh, but the exact amount and nature of silicon availability in fruit rind of cucumber has not been studied yet. Ando et al. (2012) reported a progressive development of early cucumber fruit explaining morphological changes. Initially, the warts, which tend to form at the base of spine, were diminutive at early fruit stage, and after some time, they became prominent but somewhat flattened and spaced with further fruit growth. Meanwhile, the spines which were randomly scattered at the early stage followed maturation and finally abscised at the full growth. This type of pattern showing dense cover of trichome at an early stage has further became less dense and spaced (Smith and Fleming 1979). At the time of anthesis, the dull appearance of fruit due to bloom was also noticed which gradually disappears at fruit maturity. Cucumber fruits show surface blooming due to deposition of fine silica powder $\left(\mathrm{SiO}_{2}\right)$, at origination of trichomes (Peter 2008). The possible cause of blooming is, perhaps, the $\mathrm{SiO}_{2}$ emission from trichomes, which densely cover pericarp at the development of early fruit (Peter 2008).

Samuels et al. (1993) also reported the presence of silica in cucumber fruit rind; the X-ray mapping revealed that higher silica content was restricted to trichomes, while in the surrounding area of trichome, silica content was very less. The EPMA mapping of the exocarp, in this study, also shows a very small amount of silicon in the fleshy mesocarp and endocarp in comparison to outer exocarp (Figs. 1, $2,3)$. Thus, it is evident that trichomes play a significant role of silica deposition in Cucumis sativus Linn. fruits and warts, which remain as a remnant part of abscised spine, and are potential source of silica.

In addition, cereals which are the main food materials have been found to contain higher amount of silicon; however, in fruits and vegetables, silicon has been found to present in variable amounts (Pennington 1991). Green bean, dried dates, bananas, and red lentils showed a

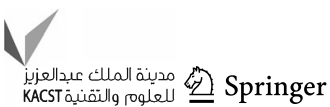




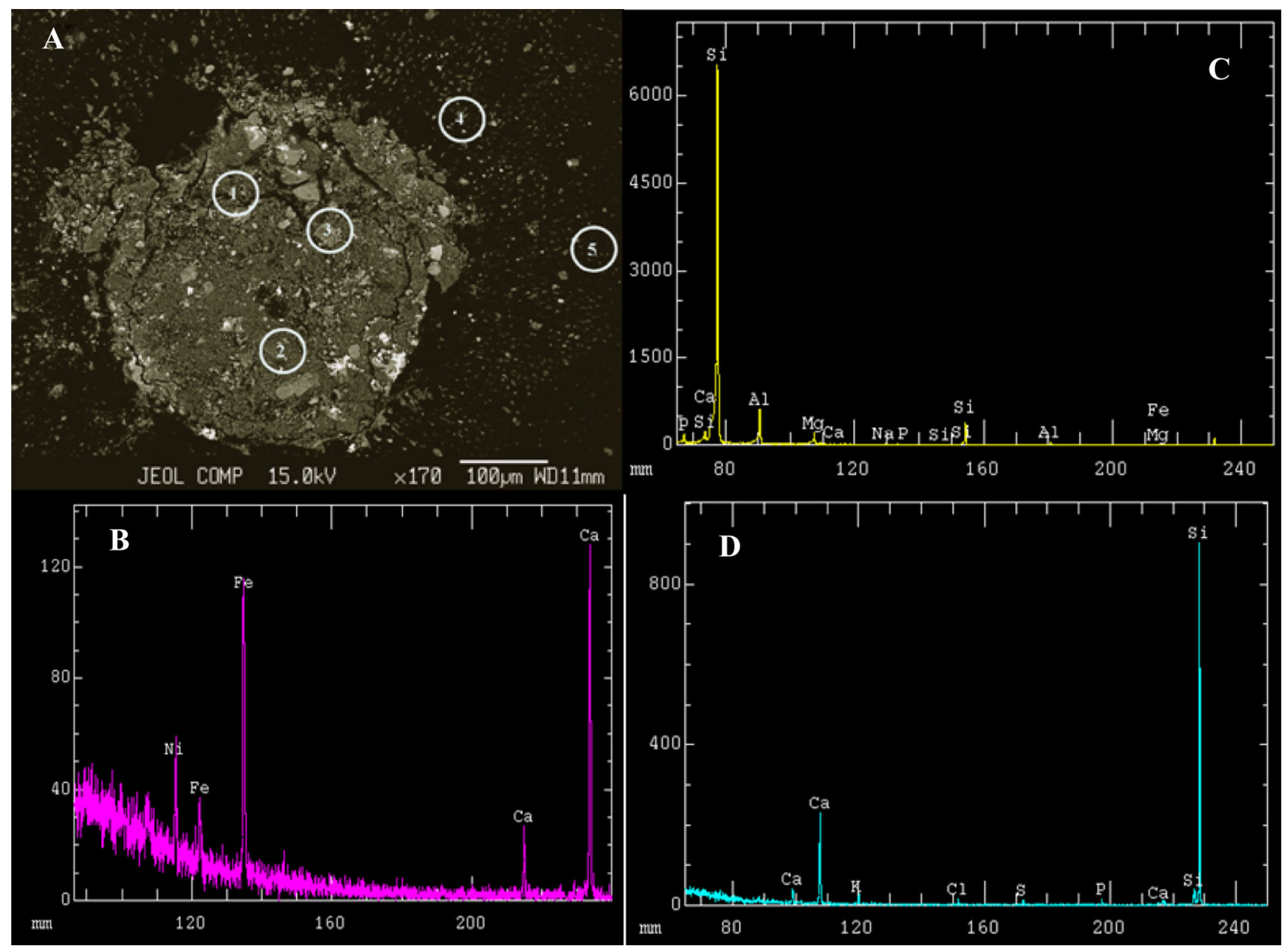

Fig. 3 Backscattered electron image (BEI) by electron probe micro-analyzer (a) and EPMA spectra of point 1 (b-d) of warty cucumber which represents the availability of silicon and other elements

significant amount of silicon contents; however, in tomatoes, oranges, and onions, silicon has been observed in a lower amount (Pennington 1991). Likewise, in different studies, Cucumis sativus Linn. has been also reported as a high silicon accumulator plant which depicted the amount like $2.53 \mathrm{mg} / 100 \mathrm{gm}$ and $3.0-4.6 \mathrm{mg} / 100 \mathrm{gm}$ of silicon (Pennington 1991). Some studies also revealed that trichomes are excellent $\mathrm{Si}$ depositors, and thus, fruits and vegetables having trichomes or refine hairs on their surface, i.e., French beans cereals, spinach, etc. (Southgate 2000) possess higher silicon contents.

Silicon has been reported as a key element of the mammalian diet, which is consumed through different plant-based foods. The main and most vital source of silicon interaction for the mass of the human population is the diet. However, they are frequently exposed by many sources including pharmaceuticals, dust, and medical implants, devices, and cosmetics (Sebastian et al. 2010; Jugdaohsingh et al. 2015). A positive association between
Si intake and bone mineral density has been reported which successfully prevent the osteoporosis (Sripanyakorn et al. 2005; Sebastian et al. 2010; Jugdaohsingh et al. 2015). The findings of Carlisle (1972) and Schwarz and Milne (1972) revealed the role of silica in bone and connective tissues. Since then, many studies have been carried out, suggesting the role of silicon in bone formation. In some osteoporotic patients, silicon supplementation was found to increase bone mineral density, marker of strong bone (Jugdaohsingh et al. 2002). In a recent study, Price et al. (2013) proposed that silica plays a significant role in prevention of postmenopausal osteoporosis, while Barel et al. (2005) studied the effect of silicon supplementations on hair, skin, nails, and found positive effect on skin firmness and less brittleness in nails and hair; thus, silicon is added in many cosmetics. Schwartz (1977) indicates that silica intake is useful for healthy blood vessels; however, it has been also found to prevent Alzheimer's disease by inhibiting absorption of aluminum, which cause disease. Therefore, 

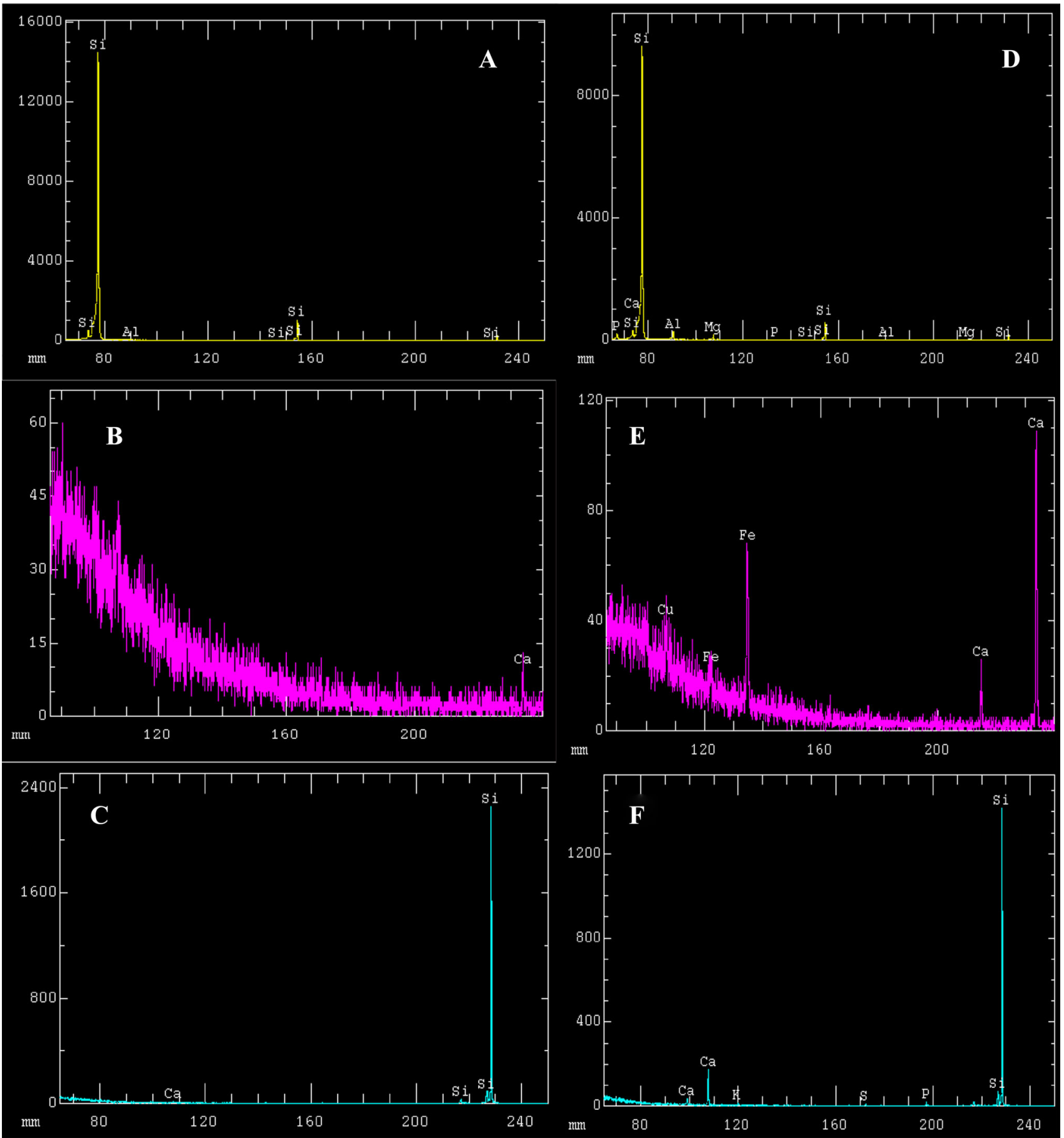

Fig. 4 EPMA spectra of point $2(\mathbf{a}-\mathbf{c})$ and point $3(\mathbf{d}-\mathbf{f})$ warty cucumber which represent the availability of silicon and other elements

monitoring of silicon deposition in food materials used on daily basis is required. Though, there are many silica food supplements now available in market in the form of tablet and solution, but the plant products provide more silicon than any other source and thus make possible to bioavailability for human consumption. 

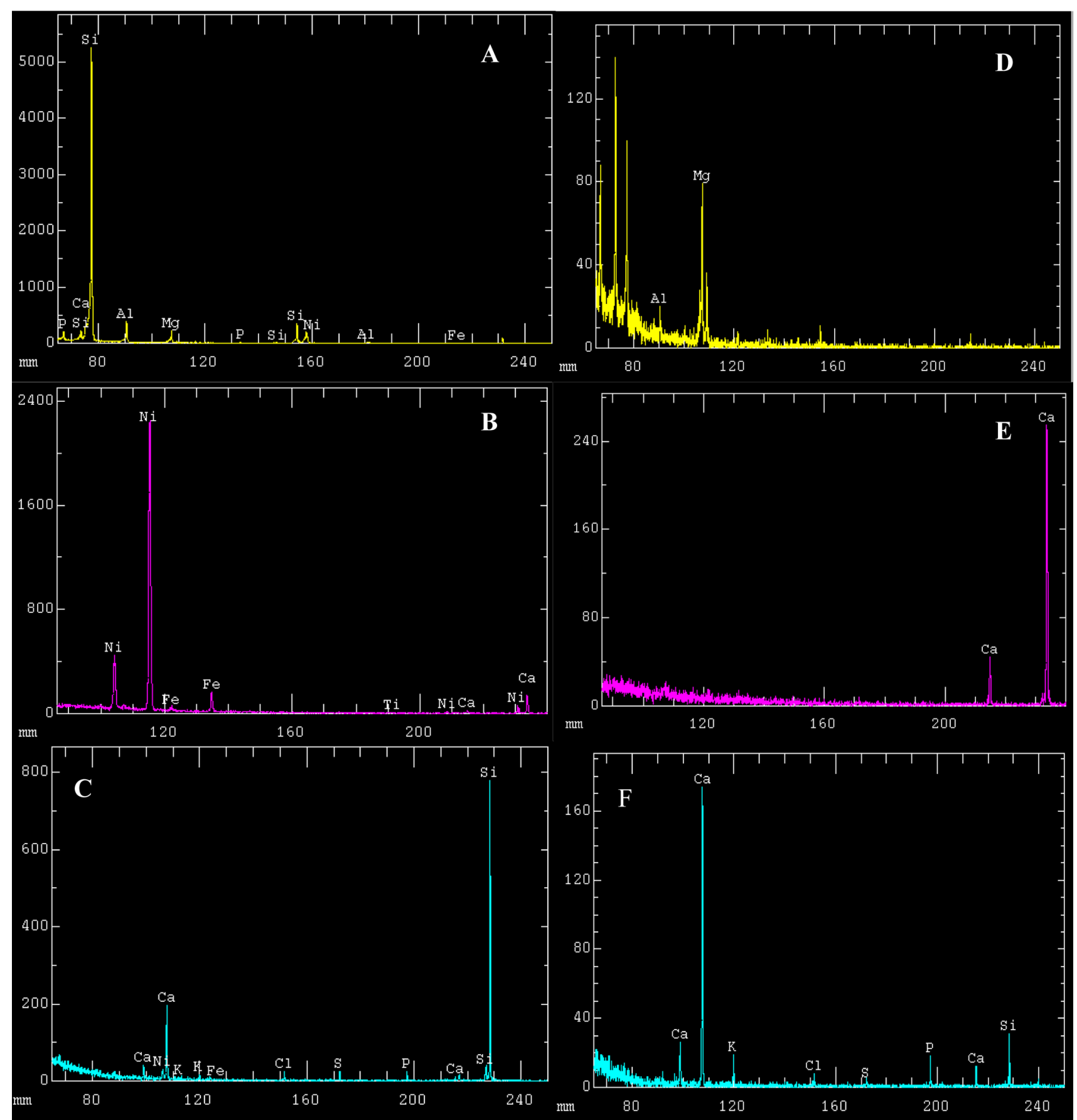

Fig. 5 EPMA spectra of point $4(\mathbf{a}-\mathbf{c})$ and point $5(\mathbf{d}-\mathbf{f})$ of warty cucumber which clearly demonstrate the presence of silicon and other elements

\section{Conclusion}

In conclusion, the present work suggests that warty cucumbers contain more silicon than smooth one. A wart being a remnant part of spine/trichome accumulates more silicon in exocarp of cucumber than other part of fruit. Silicon is considered an important trace mineral that aids in developing strong and healthy skeleton, preventing osteoporosis, Alzheimer's disease, firm skin tone, shiny hairs and nails, and various other functions. Therefore, warty cucumbers have more to offer just than some phytonutrients, vitamins, and 
Table 1 Average (\%) of elements in the warts of cucumber fruit

\begin{tabular}{|c|c|c|c|c|}
\hline Element & Minimum & Maximum & Average & Sigma \\
\hline $\mathrm{MgO}$ & - & 2.538 & 1.424 & 1.133 \\
\hline $\mathrm{Al}_{2} \mathrm{O}_{3}$ & 0.112 & 6.327 & 2.414 & 2.581 \\
\hline $\mathrm{SiO}_{2}$ & 2.072 & 99.508 & 63.536 & 38.653 \\
\hline $\mathrm{P}_{2} \mathrm{O}_{5}$ & - & 2.972 & 1.735 & 1.247 \\
\hline $\mathrm{SO}_{3}$ & - & 1.390 & 0.627 & 0.556 \\
\hline $\mathrm{Cl}$ & - & 0.424 & 0.176 & 0.202 \\
\hline $\mathrm{K}_{2} \mathrm{O}$ & - & 0.513 & 0.263 & 0.204 \\
\hline $\mathrm{CaO}$ & 0.313 & 9.691 & 4.072 & 3.482 \\
\hline $\mathrm{FeO}$ & - & 2.372 & 1.253 & 1.165 \\
\hline $\mathrm{NiO}$ & - & 30.990 & 6.377 & 13.765 \\
\hline $\mathrm{Cu}$ & - & 0.851 & 0.170 & 0.381 \\
\hline $\mathrm{Na}_{2} \mathrm{O}$ & - & 0.298 & 0.060 & 0.133 \\
\hline Total & 13.877 & 100.001 & 82.128 & 38.179 \\
\hline
\end{tabular}

minerals which they provide us a unique combination of nutrients. However, more research is needed to explore more about silica.

Acknowledgements Deepika Tripathi is thankful to University Grants Commission, New Delhi for financial support. Dr. Durgesh Kumar Tripathi further extends his thanks to University Grants Commission for providing Dr. D. S. Kothari Post Doctoral Fellowship. Authors are also thankful to the National Centre of Experimental Mineralogy and Petrology, University of Allahabad, for providing EPMA facility to determine elemental composition.

\section{Compliance with ethical standards}

Conflict of interest Authors declared that there is no conflict of interest.

\section{References}

Ando K, Carr KM, Grumet R (2012) Transcriptome analyses of early cucumber fruit growth identifies distinct gene modules associated with phases of development. BMC Genom 13:518

Barber KG (1909) Comparative histology of fruits and seeds of certain species of Cucurbitaceae. Bot Gaz 47:263-310

Barel A, Calomme M, Timchenko A, De Paepe K, Demeester N, Rogiers V, Clarys P, Vanden Berghe D (2005) Effect of oral intake of choline stabilized orthosilicic acid on skin, nails and hair in women with photodamaged facial skin. Arch Dermatol Res 297(4):147-153

Bozarth SR (1987) Diagnostic opal phytoliths from rinds of selected cucurbit species. Am Antiquity 52:607-615

Carlisle EM (1972) Silicon: an essential element for the chick. Science 178:619-662

Carlisle EM (1986) Silicon. In: Mertz W (ed) Trace elements in human and animal nutrition, vol 2, 5th edn. Academic Press, Orlando, pp 373-390

Dayanandan P, Derry LA, Kurtz AC, Ziegler K, Chadwick OA (2005) Biological control of terrestrial silica cycling and export fluxes to watersheds. Nature 433:728-731
Derry LA, Kurtz AC, Ziegler K, Chadwick OA (2005) Biological control of terrestrial silica cycling and export fluxes to watersheds. Nature 433:728-731

Epstein E (1999) Silicon. Annu Rev Plant Physiol Plant Mol Biol 50:641-664

Fuller DQ (2006) Agricultural origins and frontiers in South Asia: a working synthesis. J World Prehist 20:1-86

Harrison CC (1996) Evidence for intramolecular macromolecules containing protein from plant silicas. Phytochemistry 41:37-42

Inamdar JA, Gangadhara M (1975) Structure, ontogeny, classification and organographic distribution of trichomes in somecucurbitaceae. Feddes Reportorium 86:307-320

Jugdaohsingh R, Anderson SHC, Tucker KL, Elliott H, Kiel DP, Thompson RPH, Powell JJ (2002) Dietary silicon intake and absorption. Am J Clin Nutr 75:887-893

Jugdaohsingh R, Watson AIE, Bhattacharya P, van Lenthe GH, Powell JJ (2015) Dietary silicon intake and absorption. Osteoporosis Int 26(4):1405-1415

Kaufman PB, Cseke LJ, Warber S, Duke JA, Brielmann HL (1999) Natural products from plants. CRC Press, Boca Raton

Kayongo-Male H, Jia X (1999) Silicon bioavailability studies in young rapidly growing rats and turkeys fed semipurified diets. Biol Trace Elem Res 67(2):173-186

Paris HS, Janick J, Paris D (2011) Medieval herbal iconography and lexicography of Cucumis (cucumber and melon, Cucurbitaceae) in the Occident, 1300-1458. Ann Bot 108:471-484

Pennington JA (1991) Silicon in food and diets. Food Addit Contam 8:97-118

Peter KV (ed) (2008) Basics of horticulture. New India Publishing Agency, New Delhi, pp 166-167

Piperno DR (2006) Phytoliths. A Comprehensive Guide for Archaeologists and Paleoecologists. Altamira Press, Lanham, p 238

Powell JJ, McNaughton SA, Jugdaohsingh R, Anderson SHC, Dear J, Khot F, Mowatt L, Gleason KL, Sykes M, Thompson RP, Bolton-Smith C, Hodson MJ (2005) A provisional database for the silicon content of foods in the United Kingdom. Brit J Nutr 94:804-812

Price CT, Koval KJ, Langford JR (2013) Silicon: a review of its potential role in the prevention and treatment of postmenopausal osteoporosis. Int J Endocrinol. doi:10.1155/2013/316783

Rogalla H, Römheld V (2002) Role of leaf apoplast in siliconmediated manganese tolerance of Cucumis sativus L. Plant Cell Environ 25(4):549-555

Samuels AL, Glass ADM, Ehret DL, Menzies JG (1993) The effect of silicon supplementation on Cucumber fruit: changes in surface characteristics. Ann Bot 72:432-440

Sangster AG, Hodson MJ, Tubb HJ, Datnoff LE, Snyder HH, Korndörfer GH (2001) Silicon in agriculture. Elsevier Science, Amsterdam, pp 85-113

Schoelynck J, Bal K, Backx H, Okruszko T, Meire P, Struyf E (2010) Silica uptake in aquatic and wetland macrophytes: a strategic choice between silica, lignin and cellulose? N Phytot 186:385-391

Schwarz K, Milne DB (1972) Growth-promoting effects of silicon in rats. Nature 239(5371):333-334

Schwartz K (1977) Silicon, fibre and atherosclerosis. Lancet 309(8009):454-457

Seaborn CD, Nielsen FH (1993) Silicon deprivation decreases collagen formation in wounds and bone, and ornithine transaminase enzyme activity in liver. Nutr Today 28:13-18

Sebastian P, Schaefer H, Telford IRH, Renner SS (2010) Cucumber (Cucumis sativus) and melon (C. melo) have numerous wild relatives in Asia and Australia, and the sister species of melon is from Australia. Proc Natl Acad Sci USA 107:14269-14273 
Smith KR, Fleming HP (1979) Scanning electron microscopy of the surface of pickling cucumber fruit. $\mathrm{J}$ Amer Soc Hort Sci 104(4):523-533

Soetan KO, Olaiya CO, Oyewole OE (2010) The importance of mineral elements for humans, domestic animals and plants: a review. Afric J Food Sci 4(5):200-222

Southgate DAT (2000) Vegetables, fruits, fungi and their products. In: Garrow JS, James WPT, Ralph A (eds) Human nutrition and dietetics. Churchill-Livingstone, London

Sripanyakorn S, Jugdaohsingh R, Thompson RP, Powell JJ (2005) Dietary silicon and bone health. Nutr Bullet 30(3):222-230

Tripathi DK, Kumar R, Pathak AK, Chauhan DK, Rai AK (2012a) Laser-induced breakdown spectroscopy and Phytolith analysis: an approach to study the deposition and distribution pattern of silicon in different parts of wheat (Triticum aestivum L.) plant. Agri Res 1(4):352-361

Tripathi DK, Chauhan DK, Kumar D, Tiwari SP (2012b) Morphology, diversity and frequency based exploration of phytoliths in Pennisetum typhoides Rich. Natl Acad Sci Lett 35(4):285-289

Tripathi DK, Singh VP, Gangwar S, Prasad SM, Maurya JN, Chauhan DK (2014) Role of silicon in enrichment of plant nutrients and protection from biotic and abiotic stresses. In: Ahmad P, Wani MR, Azooz MM, Tran LSP (eds) Improvement of crops in the era of climatic changes. Springer, New York, pp. 39-56

Tripathi DK, Singh S, Singh S, Mishra S, Chauhan DK, Dubey NK (2015a) Impact of exogenous silicon addition on chromium uptake, growth, mineral elements, oxidative stress, antioxidant capacity, and leaf and root structures in rice seedlings exposed to hexavalent chromium. Acta Physiol Plant. doi:10.1007/s11738015-1870-3

Tripathi DK, Singh VP, Prasad SM, Chauhan DK, Dubey NK, Rai AK (2015b) Silicon-mediated alleviation of $\mathrm{Cr}(\mathrm{VI})$ toxicity in wheat seedlings as evidenced by chlorophyll florescence, laser induced breakdown spectroscopy and anatomical changes. Ecotox Environ Safe 113:133-144

Tripathi DK, Singh VP, Prasad SM, Dubey NK, Chauhan DK, Rai AK (2016) LIB spectroscopic and biochemical analysis to characterize lead toxicity alleviative nature of silicon in wheat (Triticum aestivum L.) seedlings. J Photochem Photobiol B 154:89-98

Tripathi DK, Shweta SS, Yadav V, Arif N, Singh S, Dubey NK, Chauhan DK (2017) Silicon: a potential element to combat adverse impact of UV-B in Plants. Mapping UV-B Research from Past to Recent Advancements. Wiley-Blackwell, pp 175195

van Dyck K, Robberecht H, van Cauwenbergh R (2000) Spectrometric determination of silicon in food and biological samples: an interlaboratory trial. J Anal At Spectrom 15:735-741

Vasanthi N, Lilly MS, Raj SA (2012) Silicon in day today life. World Appl Sci J 17:1425-1440

Welbaum GE (2015) Vegetable Production and Practices. CAB International, Wallingforth, Oxfordshire, p 486 